\title{
BMJ Global Health What will we choose to learn from the COVID-19 pandemic?
}

\author{
Alice Uwase Bayingana (D) , ${ }^{1,2}$ Agnes Binagwaho, ${ }^{3}$ Kedest Mathewos ${ }^{3}$
}

To cite: Bayingana AU, Binagwaho A, Mathewos K. What will we choose to learn from the COVID-19 pandemic?BMJ Global Health 2021;6:e007005. doi:10.1136/ bmjgh-2021-007005

Handling editor Seye Abimbola

Received 26 July 2021 Accepted 2 August 2021
Check for updates

(C) Author(s) (or their employer(s)) 2021. Re-use permitted under CC BY-NC. No commercial re-use. See rights and permissions. Published by BMJ.

${ }^{1}$ London School of Hygiene \& Tropical Medicine, London, UK ${ }^{2}$ Institute of Psychiatry, Psychology, and Neuroscience, King's College London, London, UK

${ }^{3}$ Office of the Vice Chancellor, University of Global Health Equity, Kigali, Rwanda

Correspondence to Alice Uwase Bayingana; bayinganaa@gmail.com
Now that we have highly effective vaccines against SARS-CoV-2, many in high-income countries (HICs) have started to move on from the pandemic and 'return to normal'. ${ }^{12}$ All the while, many of the working-class poor and marginalised communities in those countries who were treated like sacrificial lambs for the past year and a half are still reeling from massive loss, disability and trauma. ${ }^{3-5}$ Outside of their own countries, global representatives of HIC governments are fighting tooth and nail to control the supply and manufacture of vaccines worldwide, calling into question whether this 'return to normal' is meant to be for all of us or only a few. ${ }^{6}$

One would be rightfully shocked to recall that just 2 years ago, at the beginning of the pandemic, calls for solidarity both within and across communities and nations were the norm; many pieces were written, and speeches delivered, to celebrate and encourage acts of collective responsibility and solidarity. From the creation of the COVID-19 Vaccines Global Access (COVAX) initiative ${ }^{7}$ to the sharing of prevention strategies like wearing a mask and staying home so grandma is not put at unnecessary risk, we were all called on to make sure that we collectively had a fighting chance against this 'novel' threat.

With $86 \%$ of the world currently not fully vaccinated, the majority of whom are in low-income and middle-income countries (LMICs) with little to no vaccine access, ${ }^{8}$ this premature call for a 'return to normal', along with all the implications that it carries for those among us who have lost, and continue to lose, the most in this fight, is not only shortsighted but also insidiously violent. To 'return to normal' would mean that we have not learnt anything from this experience. We need to ask ourselves why we should want to return to a state in which we are once again vulnerable to this level of destruction and disruption from a viral threat-especially while we have had plenty of chances to learn from our mistakes. This question is exceedingly more important

\section{Summary box}

As many high-income countries started to get a handle on COVID-19 cases through mass vaccination, plans and celebrations for a 'return to normal' started to pour in.

- We need to be careful who we tell the story of the COVID-19 pandemic lest it goes down in history as an economic inconvenience instead of the mass disabling and mass death event it continues to be.

- We must remind ourselves and each other what true solidarity and shared responsibility look like.

- Only then can the systems we create stand a chance of adequately preparing us for and getting us through this current health security threat and the ones we will inadvertently encounter in the future.

now as more contagious and deadlier variants leave those unvaccinated more vulnerable. Our current response would suggest that the lesson we are choosing to take away from this is that we can get away with putting the most vulnerable in our communities on the front lines of these fights and see nothing wrong with expecting the same 'sacrifice' from them the next time around; all while refusing to provide them with the bare minimum protection and support to meet their basic needs.

Instead of this urge to return to a prepandemic normal, we should start proactively setting up systems that allow us to take better care of ourselves and each other in times of collective threat and, maybe more importantly, in times of 'normalcy'. To achieve this, we need to make sure that the lessons we learn are correct, reflect on what happened and continues to happen to the most vulnerable among us, and ensure that these lessons are turned into practice.

\section{WHO OWNS THE COVID-19 NARRATIVE?}

While everyone in the world has been affected by the pandemic, it would be incorrect to suggest that the effects have been equally felt. Some of us were asked to stay at home while others were told to continue to work, with little 
to no protection, to ensure that 'all of us' were safe, fed and cared for. The idea that the worst part of this fight is over that we see prevailing in Western popular media is not so much incorrect as it is dangerously incomplete; if the worst of the pandemic was the economic disruption and the disruption to regular social life for HICs, then the worst may very well be over with the introduction of a widely available vaccine, but the problem remains for LMICs. Nevertheless, we must remain clear about what this pandemic has been and continues to be; and that is a mass disabling and mass death event before it is an economic or social inconvenience. $^{9}$

The beginning of the pandemic featured heavy references to COVID-19 as the great equaliser but, as we look back today, we can see that the global rich came out of this largely unaffected and in some cases even better off. ${ }^{10}$ All the while, the people whose support we relied on have been consistently sacrificed by their employers and governments at the altar of profit. ${ }^{511}$ The ones who did not lose their lives but were instead disabled, either by the long-term effects of the body's battle against the infection or the traumatic effects of being used as a human shield, are being left out to dry as those among us who were arguably the least affected celebrate victory and prepare to move on. ${ }^{312}$

There is nothing new about this. As with any other collective threat, we have seen the privileged among us appropriate the bulk of the suffering that was experienced throughout the fight while being mostly personally, and collectively, insulated from it. ${ }^{13}$

Another insidious lesson currently being pushed is the notion that technological advancement, as supported by HIC economic investment, is what wins this fight. One step outside of the bubble of global economic privilege reveals that we are indeed far from getting through this. While many choose to centre the role that mRNA technology has played in the fight against this virus, it must be emphasised that technology is only as useful as its reach; the existence of viable vaccines means little to those who need them but cannot receive them due to arbitrary rules. ${ }^{14}$

Additionally, the idea of private ownership of lifesaving technology is antithetical to scientific discovery. Still, this opinion is expected from HICs who have, historically, been comfortable appropriating work built on the exploitation and suffering of Black and Brown people within their borders and across the globe. As HICs put up a fight to preserve future profits from a vaccine that could save countless lives now, we as a global community must remind ourselves that the West cannot rightfully claim the ownership of any health technology before atoning for the centuries of unethical testing of medical technology on poor Black and Brown people in HICs, and even often in their own nations. ${ }^{6}$

\section{LEARNING THE CORRECT LESSONS}

Reclaiming the COVID-19 narrative while fundamental, is not the end goal; the lesson we take from this experience matters. This is the same lesson we should have learnt from epidemics of the past; that global solidarity and collective responsibility are the real keys to getting through collective threats. It needs to be clarified what true solidarity looks like and what it is that we owe one another as people who share this planet.

Globally, while we have seen solidarity at the heart of the WHO's response to the pandemic, we have hardly seen the same from HICs and their representatives to the global stage. On the contrary, HIC nations have acted in blatant self-interest by insisting on using outdated charity models that serve their egos and do little to change the realities of vulnerable people in their borders and elsewhere. Acts of piracy, ${ }^{15}$ refusing to share mRNA technology to facilitate wider production of vaccines, undermining vaccine sharing initiatives by hoarding doses are all examples of this absence of solidarity. It would be too easy to look at the actions of HICs and conclude that solidarity was not present in this fight. That would be a fair hesitation since we have all seen the performative charade of solidarity many global and national leaders have used to reframe the callous marching of the working-class poor to their deaths, but we have also seen how real actions rooted in solidarity have protected many communities from the level of loss we have seen in other places without the same commitments.

At the community level, there was an unprecedented rise in direct action and mutual aid initiatives. ${ }^{16-18} \mathrm{New}$ tools were created, and old tools repurposed, to facilitate care for the vulnerable while allowing people to be able to seek and provide help without putting themselves or each other at risk. At the national level, many civil society and non-governmental organisations repurposed their systems and networks to address various issues that would arise as they fought against the further spread of the virus; such as provision for continuing medical care for chronic illness and expansion of socioeconomic safety nets. ${ }^{19}$ Many governments and organisations have also stepped up to facilitate national vaccine distribution efforts by partnering with initiatives such as COVAX and the Access to COVID-19 Tools (ACT) Accelerator. ${ }^{20}$

New global health threats will be appearing with more frequency because of climate change and because the world has never been more physically connected; the world needs to be equally socially connected. We stopped the world to address a viral threat to humanity. We must reflect on why this same urgency is not present when the issue to address is the myriad of threats to human and planetary life that, much like this current viral threat, disproportionately affect the most vulnerable among us. The lessons we take away from this experience must accurately reflect the fact that, in times of crisis, we consistently demand the most from those we give the least to and emphasise our collective responsibility to take better care of each other, and of this planet, we call home, if we are to stand a chance of survival.

Twitter Alice Uwase Bayingana @bayinganaa 
Contributors AUB contributed to the conceptualisation and writing of the article. $\mathrm{KM}$ contributed to the writing of the article. $\mathrm{AB}$ contributed to the writing of the article and provided technical guidance.

Funding The authors have not declared a specific grant for this research from any funding agency in the public, commercial or not-for-profit sectors.

Competing interests None declared.

Patient consent for publication Not required.

Provenance and peer review Not commissioned; internally peer reviewed.

Data availability statement There are no data in this work.

Open access This is an open access article distributed in accordance with the Creative Commons Attribution Non Commercial (CC BY-NC 4.0) license, which permits others to distribute, remix, adapt, build upon this work non-commercially, and license their derivative works on different terms, provided the original work is properly cited, appropriate credit is given, any changes made indicated, and the use is non-commercial. See: http://creativecommons.org/licenses/by-nc/4.0/.

ORCID iD

Alice Uwase Bayingana http://orcid.org/0000-0003-0501-9395

\section{REFERENCES}

1 Morton B. Covid: Boris Johnson upbeat about easing lockdown in England on 19 July: BBC News, 2021. Available: https://www.bbc. co.uk/news/uk-57681216

2 Banco E. America is ready to return to normal. Biden's CDC chief isn't so sure.: POLITICO, 2021. https://www.politico.com/news/ 2021/06/21/covid-19-cdc-rochelle-walensky-495095

3 Patel JA, Nielsen FBH, Badiani AA, et al. Poverty, inequality and COVID-19: the forgotten vulnerable. Public Health 2020;183:110-1.

4 Mena GE, Martinez PP, Mahmud AS, et al. Socioeconomic status determines COVID-19 incidence and related mortality in Santiago, Chile. Science 2021;372:eabg5298.

5 Strang P, Fürst P, Schultz T. Excess deaths from COVID-19 correlate with age and socio-economic status. A database study in the Stockholm region. Ups J Med Sci 2020;125:297-304.
6 Harman S, Erfani P, Goronga T, et al. Global vaccine equity demands reparative justice - not charity. BMJ Glob Health 2021;6:e006504.

7 WHO. COVAX: WHO, 2021. Available: https://www.who.int/ initiatives/act-accelerator/covax

8 Ritchie H, Ortiz-Ospina E, Beltekian D, et al. Coronavirus pandemic (COVID-19) OurWorldlnData.org: OurWorldInData.org, 2020. Available: https://ourworldindata.org/coronavirus

9 WHO. WHO Coronavirus (COVID-19) Dashboard, 2021. Available: https://covid19.who.int/

10 Wealth increase of 10 men during pandemic could buy vaccines for all: BBC World News, 2021. Available: https://www.bbc.co.uk/news/ world-55793575

11 Karmakar M, Lantz PM, Tipirneni R. Association of social and demographic factors with COVID-19 incidence and death rates in the US. JAMA Netw Open 2021;4:e2036462.

12 Shahbazi F, Khazaei S. Socio-economic inequality in global incidence and mortality rates from coronavirus disease 2019: an ecological study. New Microbes New Infect 2020;38:100762.

13 Burk T. Let the record show: mapping queer art and activism in New York City 1986-1995: City University of New York 2015.

14 Farmer P, Desai I, Binagwaho A. Africa can't be left to go it alone when it comes to Covid vaccines: The Guardian, 2021. Available: https://www.theguardian.com/commentisfree/2021/jul/10/africacovid-vaccines-europe-us

15 Coronavirus: US accused of 'piracy' over mask 'confiscation': BBC News, 2021. Available: https://www.bbc.co.uk/news/world52161995

16 Bell FM. Amplified injustices and mutual aid in the COVID-19 pandemic. Qualitative Social Work 2021:20:410-5.

17 Chevée A. Mutual aid in North London during the Covid-19 pandemic. social movement studies 2021:1-7.

18 van Ryneveld M, Whyle E, Brady L. What is COVID-19 teaching us about community health systems? A reflection from a rapid Community-Led mutual aid response in Cape town, South Africa. Int $J$ Health Policy Manag 2020. doi:10.34172/ijhpm.2020.167. [Epub ahead of print: 01 Sep 2020].

19 Umutesi G, Shyirambere C, Bigirimana JB, et al. Cancer care delivery innovations, experiences and challenges during the COVID-19 pandemic: the Rwanda experience. J Glob Health 2021;11:03067.

20 Eccleston-Turner $\mathrm{M}$, Upton $\mathrm{H}$. International collaboration to ensure equitable access to vaccines for COVID-19: the ACT-Accelerator and the COVAX facility. Milbank Q 2021;99:426-49. 